\title{
Influence of air humidity and temperature on thermal conductivity of wood-based materials
}

\author{
Maciej Trochonowicz, Monika Galas \\ Department of Conservation of Built Heritage, Civil Engineering and Architecture Faculty, Lublin \\ University of Technology, Nadbystrzycka 40 Str.,20-618 Lublin, m.trochonowicz@pollub.pl
}

\begin{abstract}
The aim of this paper is to approximate the issues related to the influence of air humidity and test temperature on the thermal conductivity coefficient $\lambda$ of wood-based materials. During the laboratory tests, the $\lambda$ coefficient was determined depending on the test temperature and air humidity, material density and sorption were also tested.
\end{abstract}

Keywords: wood-based materials, thermal conductivity coefficient, thermal insulation.

\section{Introduction}

The paper aims to familiarize the research on thermal conductivity in wood-based materials. During the tests, the values of thermal conductivity coefficient were determined for various types of wood-based panels used in the construction industry.

During the laboratory tests, the thermal conductivity coefficient was determined depending on the test temperature and air humidity. The temperature-dependent coefficient was determined on 29 samples. 5 types of plates were selected for further research. Each type was tested in three temperature ranges. The next group of tests included the determination of the $\lambda$ thermal conductivity coefficient for different air humidity of the sample tested. The test was done on samples at five different air humidity values. The tests were carried out on five types of fibreboards. On the basis of the results, the graphs were created on which the relationships between the $\lambda$ coefficients, test temperature, air humidity, and material density are shown. The sorption curves have also been determined. The obtained test results are presented in the form of tables and graphs.

\section{Test stand}

The tests were carried out using the Laser Comp FOX314 device, which consists of a base and a measuring chamber. The base includes a display with a keyboard to operate the device. The sample can be placed in the device after opening the door of the measuring chamber. The top plate of the instrument is fixed, the lower one has the ability to move up and down with the help of four stepper motors. After taking the sample through the plates, an average height value is read from four sensors with an accuracy of $\pm 0.025 \mathrm{~mm}$.

To remove the radial temperature gradient in the plates, they were equipped with a heating and cooling system, which consist of groups of thermoelectric elements, monitored separately for each of the plates. When the coolant temperature is maintained at $18^{\circ} \mathrm{C}$, the plates can reach independent temperatures in the range of $0^{\circ} \mathrm{C}$ to $95^{\circ} \mathrm{C}$ with an accuracy of $\pm 0.02^{\circ} \mathrm{C}$. [1] 
To check the accuracy of measurements, the device was calibrated using a mineral wool sample numbered as $\mathrm{S} 117$, density equal to $76.7 \mathrm{~kg} / \mathrm{m}^{3}$, and dimensions of $301 \mathrm{~mm}$ x $301 \mathrm{~mm}$ $\mathrm{x} 34.2 \mathrm{~mm}$ (length $\mathrm{x}$ width $\mathrm{x}$ thickness). Due to the possibility of crushing the sample with automatic thickness measurement, the thickness was entered manually. A temperature range of $10-30^{\circ} \mathrm{C}$ was selected for the measurements, which corresponds to the range included in the instrument's manual. [2] The error of the calibration measurement was $0.22 \%$, with a maximum permissible error of $2 \%$, which means that the calibration of the device was carried out correctly.

\section{Specimens tests}

The plates collected were dried to a constant weight in an oven at $70^{\circ} \mathrm{C}$. The determination of the thermal conductivity coefficient was carried out on 29 samples. The measurements were made using a stationary method in the Laser Comp FOX 314 device. The course of the study was controlled using the WinTherm $32 \mathrm{v} 3$ software. Each of the samples was tested in one range, at a temperature of $12.5^{\circ} \mathrm{C}$ (lower plate temperature $L=0^{\circ} \mathrm{C}$, upper $U=25^{\circ} \mathrm{C}$ ). The results obtained are presented in Table 1.

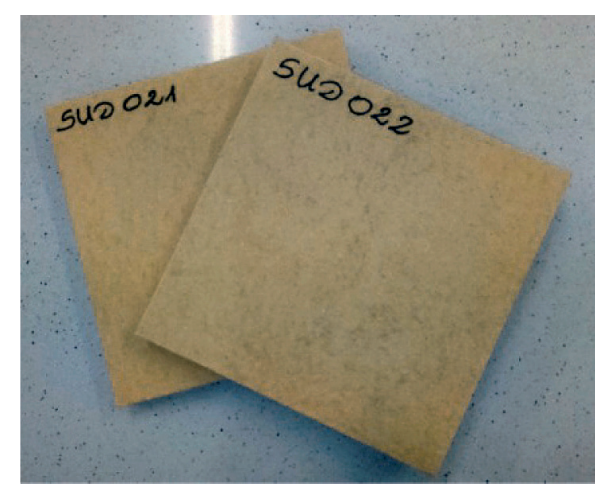

Fig. 1. Identification of the SUD 021 and SUD 022 samples. Thermo-insulating fibreboard $-200 \mathrm{~kg} / \mathrm{m}^{3}$

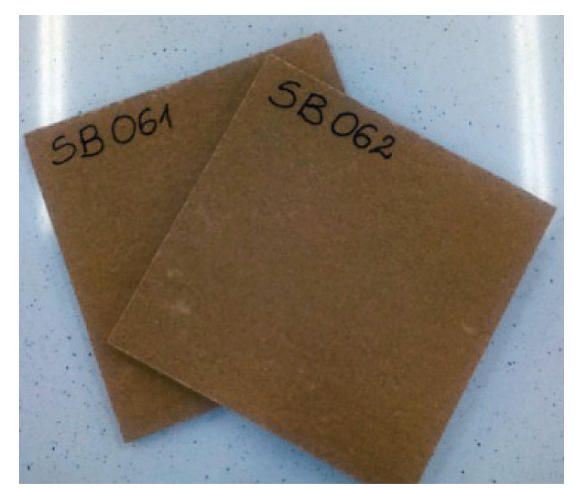

Fig. 3. Identification of the SB 061 and SB 062 samples. Insulating fibreboard $-240 \mathrm{~kg} / \mathrm{m}^{3}$

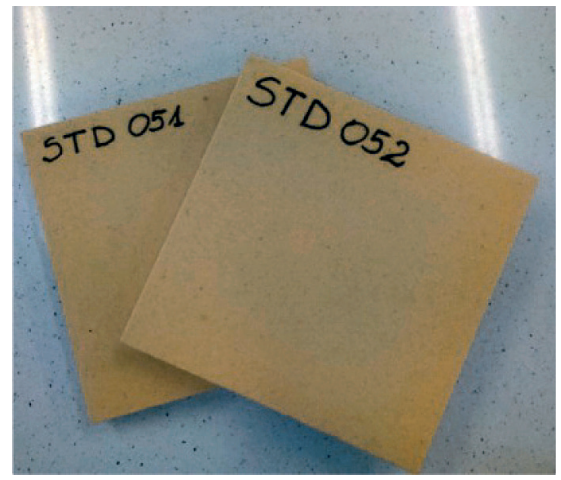

Fig. 2. Identification of the STD 051 and STD 052 samples. Insulating fibreboard $-210 \mathrm{~kg} / \mathrm{m}^{3}$

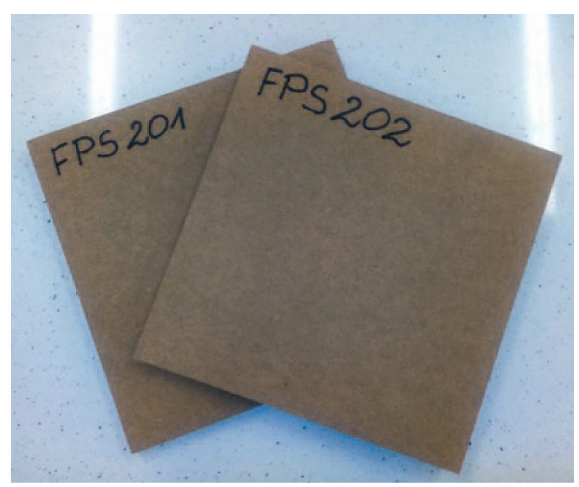

Fig. 4. Identification of the FPS 201 and FPS 202 samples. Porous fibreboard $-290 \mathrm{~kg} / \mathrm{m}^{3}$ 


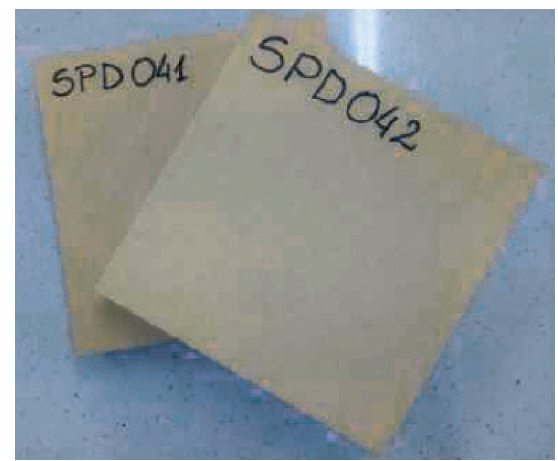

Fig. 5. Identification of the SPD 041 and SPD 042 samples. Insulating fibreboard $-160 \mathrm{~kg} / \mathrm{m}^{3}$

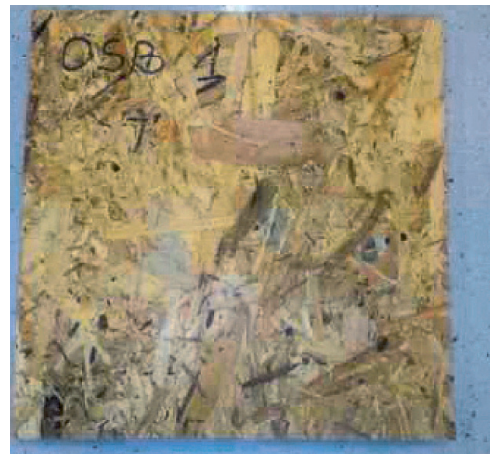

Fig. 6. Identification of the OSB 1 sample $560 \mathrm{~kg} / \mathrm{m}^{3}$

Table 1. Results of the thermal conductivity coefficient of samples at $12.5^{\circ} \mathrm{C}$

\begin{tabular}{|c|c|c|c|c|c|}
\hline \multirow{3}{*}{$\begin{array}{l}\text { The desigantion } \\
\text { of the sample }\end{array}$} & \multirow{3}{*}{$\begin{array}{l}\text { Type of } \\
\text { material }\end{array}$} & \multirow{3}{*}{$\begin{array}{l}\text { Density } \\
{\left[\mathrm{kg} / \mathrm{m}^{3}\right]}\end{array}$} & $\lambda[\mathrm{W} / \mathrm{mK}]$ & $\begin{array}{l}\lambda \text { average } \\
\text { examined }\end{array}$ & $\begin{array}{c}\text { Manufactur- } \\
\text { ers's } \lambda\end{array}$ \\
\hline & & & \multicolumn{3}{|l|}{$\begin{array}{l}\text { Temperature } \\
\text { range }\end{array}$} \\
\hline & & & $U 1=0 ; L 1=25$ & {$[\mathrm{~W} / \mathrm{mK}]$} & {$[\mathrm{W} / \mathrm{mK}]$} \\
\hline SP011 & \multirow{2}{*}{ Insulating fibreboard } & 256 & 0.04751 & \multirow{2}{*}{0.048} & \multirow{2}{*}{0.050} \\
\hline SP012 & & 257 & 0.04765 & & \\
\hline SUD021 & \multirow{2}{*}{ Thermo-insulating fibreboard } & 198 & 0.04392 & \multirow{2}{*}{0.044} & \multirow{2}{*}{0.045} \\
\hline SUD022 & & 200 & 0.04410 & & \\
\hline ST031 & \multirow{2}{*}{ Insulating fibreboard } & 147 & 0.03800 & \multirow{2}{*}{0.038} & \multirow{2}{*}{0.038} \\
\hline ST032 & & 147 & 0.03799 & & \\
\hline SPD041 & \multirow{2}{*}{ Insulating fibreboard } & 161 & 0.04151 & \multirow{2}{*}{0.041} & \multirow{2}{*}{0.043} \\
\hline SPD042 & & 160 & 0.04141 & & \\
\hline STD051 & \multirow{2}{*}{ Thermo-insulating fibreboard } & 109 & 0.03772 & \multirow{2}{*}{0.038} & \multirow{2}{*}{0.037} \\
\hline STD052 & & 108 & 0.03786 & & \\
\hline SB061 & \multirow{2}{*}{ Insulating fibreboard } & 240 & 0.04512 & \multirow{2}{*}{0.045} & \multirow{2}{*}{0.048} \\
\hline SB062 & & 238 & 0.04484 & & \\
\hline SU071 & \multirow{2}{*}{ Thermo-insulating fibreboard } & 266 & 0.04691 & \multirow{2}{*}{0.047} & \multirow{2}{*}{0.048} \\
\hline SU072 & & 266 & 0.04704 & & \\
\hline SPH081 & Insulating fibreboard & 344 & 0.05344 & 0.053 & 0.050 \\
\hline FI091 & Fibreboard & 309 & 0.04504 & 0.045 & 0.05 \\
\hline FPT101 & Hard fibreboard & 905 & 0.07295 & 0.073 & - \\
\hline FPS201 & \multirow{2}{*}{ Porous fibreboard } & 289 & 0.04815 & \multirow{2}{*}{0.048} & \multirow{2}{*}{0.05} \\
\hline FPS202 & & 288 & 0.04813 & & \\
\hline FW301 & \multirow{2}{*}{ Porous fibreboard } & 290 & 0.04880 & \multirow{2}{*}{0.049} & 0050 \\
\hline FW302 & & 289 & 0.04870 & & 0.050 \\
\hline FT401 & Fibreboard & 168 & 0.03808 & 0.038 & 0.040 \\
\hline FT402 & & 169 & 0.03808 & & \\
\hline Chipboard 1 & & 635 & 0.10220 & 0.102 & - \\
\hline Chipboard 2 & Chipboard & 590 & 0.09561 & 0.096 & - \\
\hline Chipboard 3 & & 643 & 0.10130 & 0.101 & - \\
\hline OSB 1 & OSB & 561 & 0.08816 & 0.088 & - \\
\hline Plywood 1 & Plywend & 710 & 0.12730 & 0.127 & - \\
\hline Plywood 2 & PTywood & 629 & 0.11640 & 0.116 & - \\
\hline
\end{tabular}


After analyzing the results obtained for further research, five types of fibreboards with different densities were selected, two pieces from each density. Ten samples selected were dried at $70^{\circ} \mathrm{C}$ to a humidity of about $0 \%$. The tests were carried out for three temperature levels: $22.5^{\circ} \mathrm{C}, 32.5^{\circ} \mathrm{C}$, and $42.5^{\circ} \mathrm{C}$.

Table 2. Temperature ranges used to the $\lambda$ examination, using the Laser Comp FOX314 device

\begin{tabular}{ccc}
\hline $\begin{array}{c}\text { The temperature of } \\
\text { the upper plate }\end{array}$ & $\begin{array}{c}\text { The temperature of } \\
\text { the lower plate }\end{array}$ & $\begin{array}{c}\text { The temperature } \\
\text { inside the sample }\end{array}$ \\
\hline$U 1=0^{\circ} \mathrm{C}$ & $L 1=25^{\circ} \mathrm{C}$ & Tavrg $=12.5^{\circ} \mathrm{C}$ \\
\hline$U 2=10^{\circ} \mathrm{C}$ & $L 2=35^{\circ} \mathrm{C}$ & Tavrg $=22.5^{\circ} \mathrm{C}$ \\
\hline$U 3=20^{\circ} \mathrm{C}$ & $L 3=45^{\circ} \mathrm{C}$ & Tavrg $=32.5^{\circ} \mathrm{C}$ \\
\hline$U 4=30^{\circ} \mathrm{C}$ & $L 4=55^{\circ} \mathrm{C}$ & Tavrg $=42.5^{\circ} \mathrm{C}$ \\
\hline
\end{tabular}

After each test, the samples were placed in the dryer so that the humidity was kept within $0 \%$ with each subsequent test. Below a table with results (Table 3 ) is placed, an exemplary graph with the relation of the $\lambda$ coefficient and the test temperature (Fig. 7), a collective plot of the average values of the fibreboards tested (Fig. 8), and a bar graph of the average values of the $\lambda$ coefficient.

Table 3. The values of the $\lambda$ thermal conductivity coefficient depending on the test temperature

\begin{tabular}{|c|c|c|c|c|c|}
\hline \multirow{3}{*}{$\begin{array}{l}\text { The designation of } \\
\text { the sample }\end{array}$} & \multirow{3}{*}{$\begin{array}{l}\text { Producer's } \lambda \\
{[\mathrm{W} /(\mathrm{mK})]}\end{array}$} & \multicolumn{4}{|c|}{$\lambda[\mathrm{W} / \mathrm{mK}]$} \\
\hline & & \multicolumn{4}{|c|}{ Temperature range } \\
\hline & & $U 1=0 ; L 1=25$ & $U 2=10 ; L 2=35$ & $U 3=20 ; L 3=45$ & $U 4=30 ; L 4=55$ \\
\hline SUD021 & \multirow{2}{*}{0.045} & 0.04392 & 0.04608 & 0.04591 & 0.04731 \\
\hline SUD022 & & 0.04410 & 0.04523 & 0.04661 & 0.04770 \\
\hline STD051 & \multirow{2}{*}{$(0.037$} & 0.03772 & 0.03901 & 0.04011 & 0.04090 \\
\hline STD052 & & 0.03786 & 0.0391 & 0.04011 & 0.04114 \\
\hline SB061 & \multirow{2}{*}{0.048} & 0.04512 & 0.04647 & 0.04797 & 0.04857 \\
\hline SB062 & & 0.04484 & 0.04597 & 0.04700 & 0.04764 \\
\hline FPS201 & \multirow{2}{*}{0.05} & 0.04815 & 0.04938 & 0.05040 & 0.05127 \\
\hline FPS202 & & 0.04813 & 0.04936 & 0.05040 & 0.05135 \\
\hline FT401 & \multirow{2}{*}{0.040} & 0.03808 & 0.03925 & 0.04029 & 0.04115 \\
\hline FT402 & & 0.03808 & 0.03932 & 0.04032 & 0.04107 \\
\hline
\end{tabular}

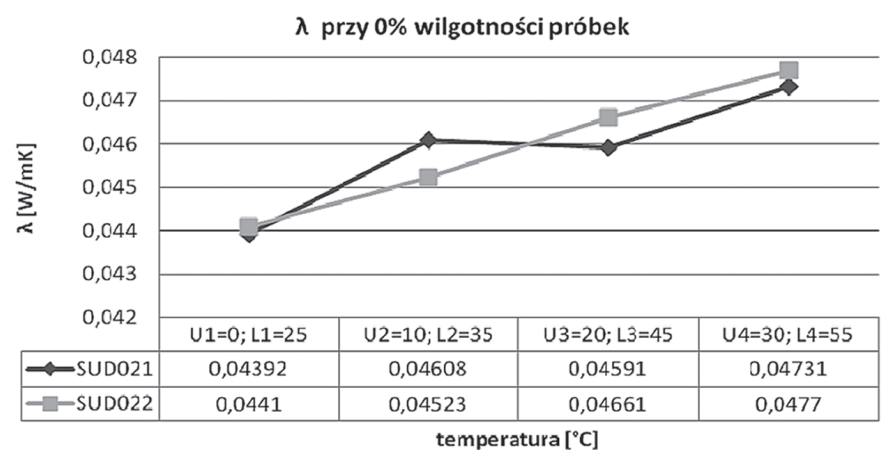

Fig. 7. The dependence of the $\lambda$ thermal conductivity coefficient and the test temperature - the SUD02 material SUD02, samples 1 and 2 


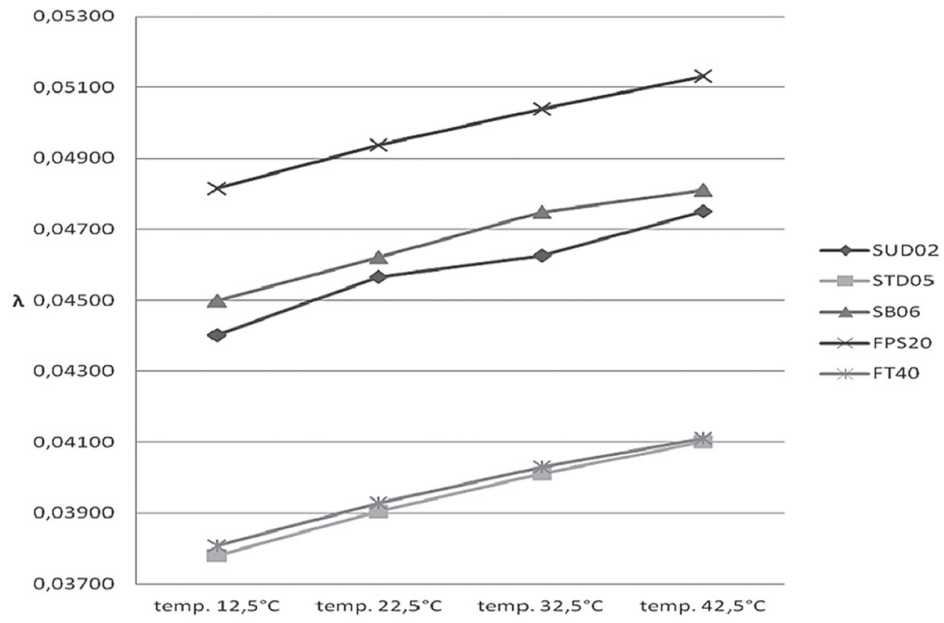

Fig. 8. A collective graph of the dependence between of the $\lambda$ thermal conductivity coefficient and the temperature. Graph was developed for the average of two samples

In all studied wood-based panels, the diagrams show a course close to linear. To compare the influence of the test temperature on the thermal conductivity of selected materials, a graph of the percentage increase in the $\lambda$ coefficient was made, assuming that the base value is the value of $\lambda$ determined at an average temperature of $12.5^{\circ} \mathrm{C}$. From the results obtained, it can be seen that for all materials, the percentage increase in $\lambda$ was similar.

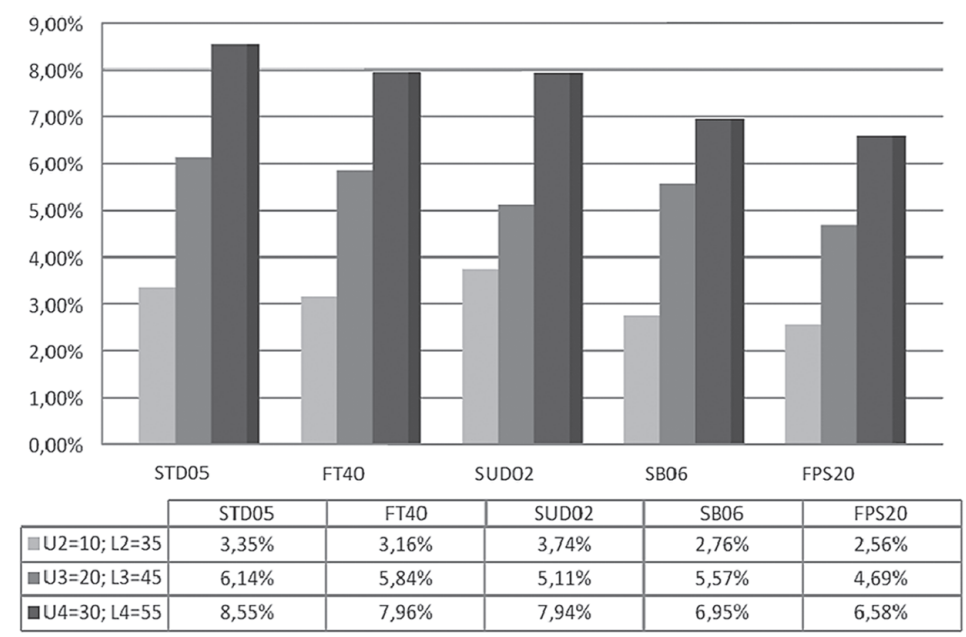

Fig. 9. The percentage increase in the $\lambda$ thermal conductivity coefficient depending on the temperature range. The reference level is the value of the $\lambda$ coefficient at a temperature of $12.5^{\circ} \mathrm{C}$.

\section{Study of sorption properties}

The purpose of the analysis was to investigate the amount of water that can be absorbed by the samples under the particular climatic conditions. For this test, the samples were dried to a constant mass, then placed in a climatic chamber in which the humidity was gradually raised 
without changing the temperature $\left(25^{\circ} \mathrm{C}\right)$. Initially, the lowest of the humidity selected for testing was set. Samples were weighed periodically until their weight was settled. The amount of water absorbed was determined at the moment when the sample mass stabilized. Correlation between air humidity and sorption humidity is shown by the sorption curves. A table with results (Table 4) and an example of a sorption curve chart are shown below (Fig. 10).

Table 4. The values of the equivalent sorption humidity of the materials tested in different air humidity

\begin{tabular}{cccccc}
\hline \multirow{2}{*}{$\begin{array}{c}\text { The designation of } \\
\text { the sample }\end{array}$} & $0 \%$ & $32-33 \%$ & $70-75 \%$ & $80-85 \%$ & $90-95 \%$ \\
\cline { 2 - 6 } & 0.00 & 5.80 & 11.14 & 13.37 & 16.53 \\
\hline SUD02 & 0.00 & 5.70 & 11.37 & 13.27 & 16.34 \\
\hline STD05 & 0.00 & 6.03 & 12.81 & 15.47 & 19.10 \\
\hline SB06 & 0.00 & 5.42 & 10.75 & 14.02 & 17.32 \\
\hline FPS20 & 0.00 & 5.70 & 12.20 & 15.73 & 19.64 \\
\hline FT40 & & & & & \\
\hline
\end{tabular}

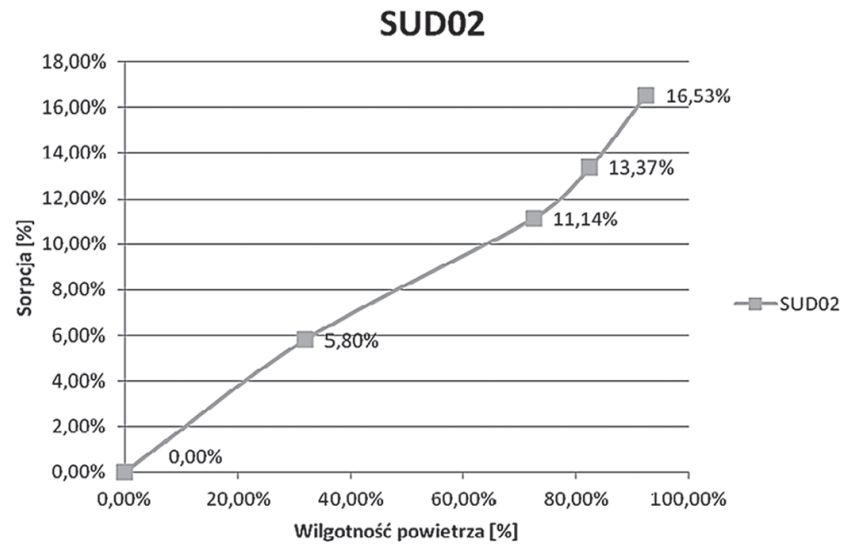

Fig. 10. Sorption curve of the SUD02 sample

There is no information on the size of sorption in the manufacturers' technical sheets, therefore the values obtained can not be compared and assessed of compliance with the declared values.

\section{Effect of air humidity}

To determine the effect of air humidity on the thermal conductivity coefficient, five types of wood-based panels of varying density were selected and placed in a climatic chamber. Samples were seasoned at air humidity equal to $32-33 \%, 70-75 \%, 80-85 \%$, and $90-95 \%$ to stabilize the sample mass. Each time, the humidity in the climatic chamber was controlled using a hytherograph.

All materials were tested in a one temperature of $12.5^{\circ} \mathrm{C}$. Each of the samples was weighed at $0 \%$ moisture and at each subsequent in which it was seasoned. Below is an example of a table with results (Tab. 5), a graph showing the dependence of the $\lambda$ coefficient and air 
humidity for two samples from the same material (Fig. 11), a collective plot of the $\lambda$ coefficient and the air humidity of the fibreboards tested (Fig. 12), and bar graph for average results of the $\lambda$ coefficient. The types of boards were arranged in order of increasing density. (Fig. 13).

Table 5. The results of the impact of air humidity on the $\lambda$ coefficient for five selected materials

\begin{tabular}{cccccc}
\hline \multirow{2}{*}{$\begin{array}{c}\text { The designation of } \\
\text { the sample }\end{array}$} & $0 \%$ & $32-33 \%$ & $70-75 \%$ & $80-85 \%$ & $90-95 \%$ \\
\cline { 2 - 6 } & 0.04401 & 0.050170 & 0.057360 & 0.059740 & 0.063575 \\
\cline { 2 - 6 } & 0.03779 & 0.044230 & 0.052185 & 0.055380 & 0.059125 \\
\hline SUD02 & 0.04498 & 0.049065 & 0.053975 & 0.056480 & 0.058730 \\
\hline STD05 & 0.04814 & 0.052305 & 0.056380 & 0.060495 & 0.064075 \\
\hline SB06 & 0.03808 & 0.042395 & 0.048225 & 0.052065 & 0.056235 \\
\hline FPS20 & & & &
\end{tabular}

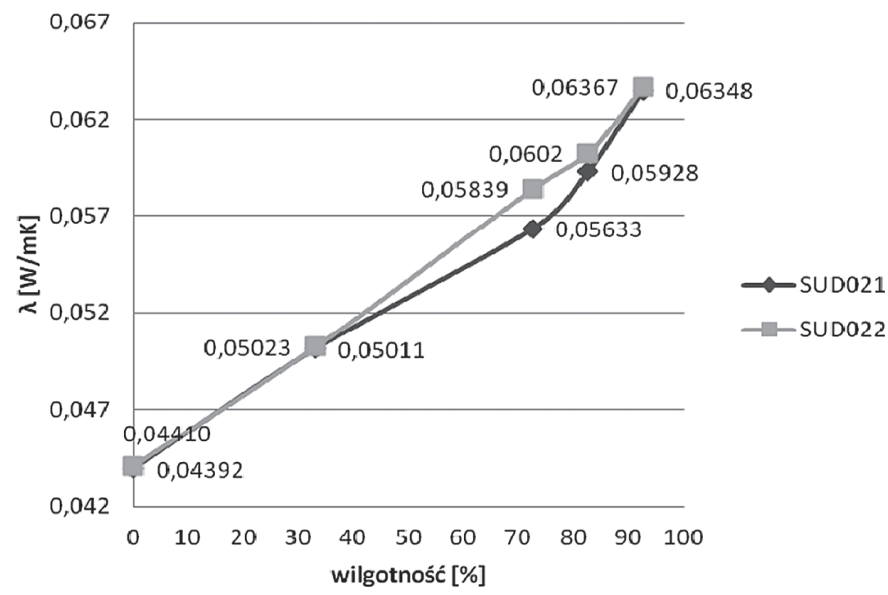

Fig. 11. The dependence of the $\lambda$ coefficient and the air humidity for SUD02

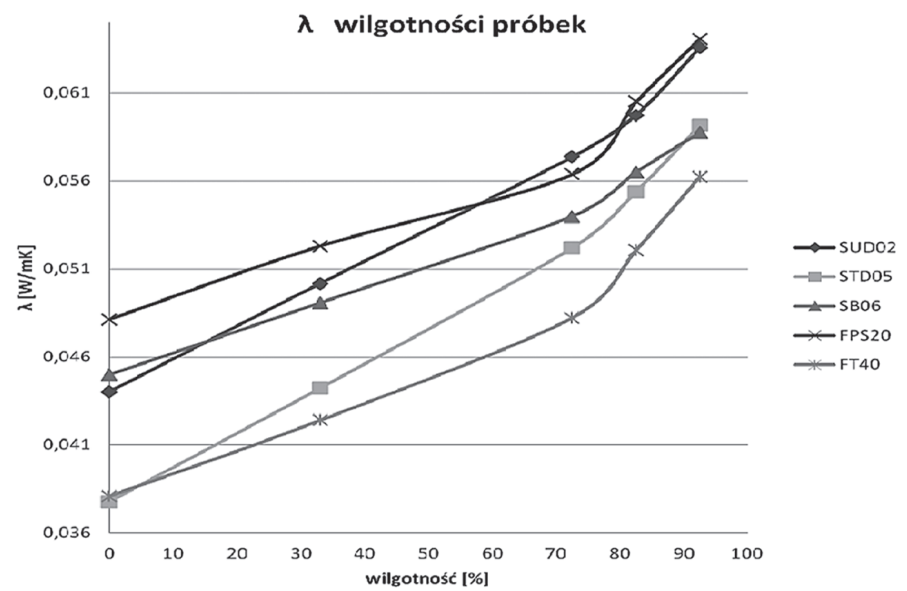

Fig. 12. Average dependence of the $\lambda$ coefficient and air humidity of all samples 
The graphs show a non-linear course of the dependencies. With each material examined, it was observed that the thermal conductivity coefficient increases with increasing humidity.

I order to compare the impact of air humidity on the thermal conductivity of selected materials, a graph of the percentage increase in the $\lambda$ coefficient was made, assuming that the base value is the value of $\lambda$ determined at $0 \%$ humidity. Different sizes of the increase in the $\lambda$ thermal conductivity coefficient for materials determined at similar humidity may result from the different structure of the material, density, and sorption capacity.

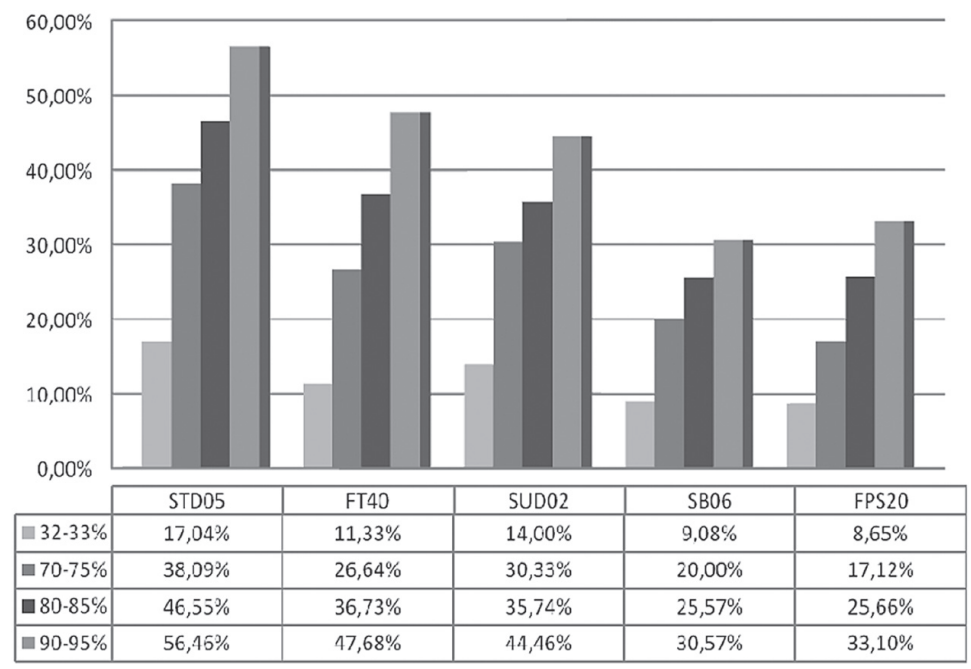

Fig. 13. The percentage increase in the $\lambda$ coefficient value depending on the air humidity

\section{Effect of density of materials}

In order to determine the effect of density of wood-based materials on the thermal conductivity coefficient, the table presents the results of samples density and the $\lambda$ coefficient values obtained from tests carried out on samples with $0 \%$ moisture and tested at $12.5^{\circ} \mathrm{C}$.

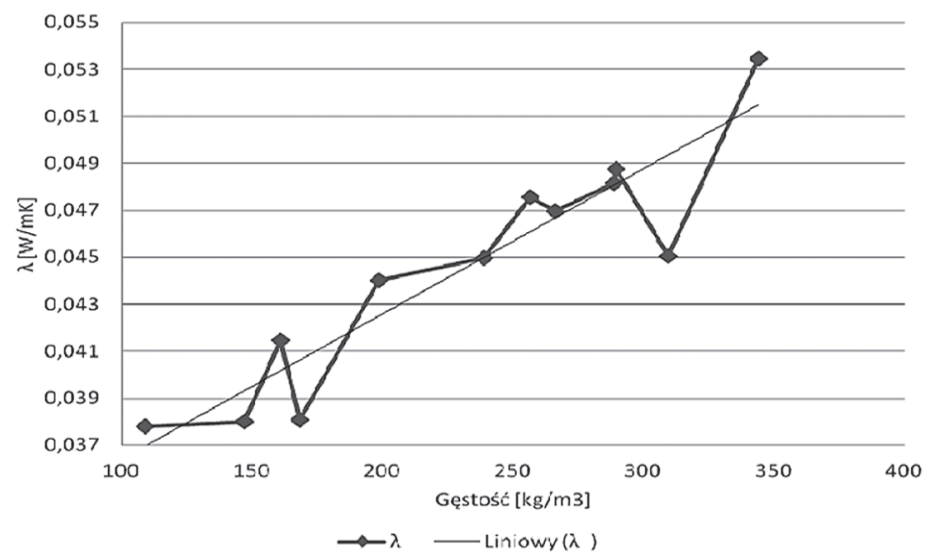

Fig. 14. Graph of dependence of the thermal conductivity coefficient and the density of materials tested 
Table 6. The values of the thermal conductivity coefficient in terms of materials' density

\begin{tabular}{ccc}
\hline \multirow{2}{*}{$\begin{array}{c}\text { The designation of } \\
\text { the sample }\end{array}$} & Density (average) & $\lambda$ tested (average) \\
\cline { 2 - 3 }$\left[\begin{array}{cc}{\left[\mathrm{kg} / \mathrm{m}^{3}\right]} \\
\text { SP01 }\end{array}\right.$ & 256 & 0.04758 \\
\hline SUD02 & 199 & 0.04401 \\
\hline ST03 & 147 & 0.03800 \\
\hline SPD04 & 161 & 0.04146 \\
\hline STD05 & 109 & 0.03779 \\
\hline SB06 & 239 & 0.04498 \\
\hline SU07 & 266 & 0.04698 \\
\hline SPH081 & 344 & 0.05344 \\
\hline FI091 & 309 & 0.04504 \\
\hline FPT101 & 905 & 0.07295 \\
\hline FPS20 & 288 & 0.04814 \\
\hline FW30 & 289 & 0.04875 \\
\hline FT40 & 168 & 0.03808 \\
\hline Chipboard 1 & 635 & 0.10220 \\
\hline Chipboard 2 & 590 & 0.09561 \\
\hline Chipboard 3 & 643 & 0.10130 \\
\hline OSB 1 & 561 & 0.08816 \\
\hline Plywood 1 & 710 & 0.12730 \\
\hline Plywood 2 & 629 & 0.11640 \\
\hline
\end{tabular}

The trend line shows an increase in the thermal conductivity coefficient with increasing density. The graph obtained does not illustrate the actual situation, because the values should be more similar to the trend line, such a discrepancy may be related to various methods and the specificity of the process of fibreboards production.

\section{Conclusions}

- There is too little information in the technical specifications.. The information on the temperature and air humidity in which the thermal conductivity coefficient was determined has not been included,

- The $\lambda$ coefficient determined at $0 \%$ moisture of the samples and the temperature of $12.5^{\circ} \mathrm{C}$ in all tested samples was close to the one declared by the producers, which may mean that this coefficient was determined by the manufacturers in similar conditions.

- For most materials the thermal conductivity coefficient value declared by the manufacturer was higher than that obtained in the laboratory.

- Regardless of the type of wood-based boards, as the temperature of the test rises, the thermal conductivity coefficient also increases. When the test temperature increased from $12.5^{\circ} \mathrm{C}$ to $42.5^{\circ} \mathrm{C}$, the percentage increase in the thermal conductivity coefficient ranged from $2.56 \%$ to $8.55 \%$.

- There is no information on the value of sorption in the manufacturers' technical sheets, therefore the values obtained can not be compared and assessed of compliance with the values declared. 
- The thermal conductivity coefficient increases with increasing humidity. With an increase in air humidity from $0 \%$ to $95 \%$, the percentage increase in the thermal conductivity coefficient ranged from $8.65 \%$ to $56.46 \%$.

- When testing the effect of density on the thermal conductivity coefficient, a graph that does not show the actual situation was obtained, the values should be closer to the trend line. Such a discrepancy may be related to various methods and the specificity of the manufacturing process of wood-based materials.

\section{Bibliography}

[1] Garbalińska H., Bochenek M. Ocena możliwości wyznaczania izoterm sorpcji dynamiczna metoda DVS - na przyktadzie betonu komórkowego klasy 700, Czasopismo Inżynierii Lądowej, Środowiska i Architektury JCEEA, XXXIV (64) (2/II) (2017) 245-252.

[2] Instrukcja obsługi instrumentu Laser Comp FOX 314.

[3] PN-EN 12524:2000 Materiaty i wyroby budowlane - Właściwości cieplno-wilgotnościowe - Tabelaryczne wartości obliczeniowe.

[4] PN-EN ISO 10456:2009 Materiaty i wyroby budowlane - Właściwości cieplno-wilgotnościowe - Tabelaryczne wartości obliczeniowe.

[5] Praca zbiorowa pod kierunkiem P. Klemma: Budownictwo ogólne. Tom 1. Materiaty i wyroby budowlane. Arkady, Warszawa 2005.

[6] Praca zbiorowa pod kierunkiem P. Klemma: Budownictwo ogólne. Tom 2. Fizyka budowli. Arkady, Warszawa 2005.

[7] Trochonowicz M., Kołodziejczuk N. Wpływ temperatury, wilgotności i kierunku badań na wartość współczynnika przewodności cieplnej $\lambda$ w różnych gatunkach drewna, Budownictwo i Architektura 14(4) (2015) 149-156.

[8] Trochonowicz M., Witek B., Chwiej M. Analiza wplywu wilgotności t temperatury powietrza na wartość wspótczynnika przewodności cieplnej $\lambda$ materiatów termoizolacyjnych stosowanych wewnątrz pomieszczeń, Budownictwo i Architektura 12(4) (2013) 164-176. 